\title{
Cross-talk between the Tissue Factor/ coagulation factor Vlla complex and the tyrosine kinase receptor EphA2 in cancer
}

\author{
Oskar Eriksson ${ }^{1 *}$, Åsa Thulin ${ }^{1}$, Anna Asplund ${ }^{2}$, Geeta Hegde ${ }^{3}$, Sanjay Navani ${ }^{3}$ and Agneta Siegbahn ${ }^{1 *}$
}

\begin{abstract}
Background: Tissue Factor (TF) forms a proteolytically active complex together with coagulation factor VIla (FVIla) and functions as the trigger of blood coagulation or alternatively activates cell signaling. We recently described that EphA2 of the Eph tyrosine kinase receptor family is cleaved directly by the TF/FVIla complex. The aim of the present study was to further characterize the cross-talk between TF/FVIla and EphA2 using in vitro model systems and human cancer specimens.

Methods: Cleavage and phosphorylation of EphA2 was studied by Western blot. Subcellular localization of TF and EphA2 was investigated by a proximity ligation assay and confocal microscopy. Phalloidin staining of the actin cytoskeleton was used to study cell rounding and retraction fiber formation. Expression of TF and EphA2 in human colorectal cancer specimens was examined by immunohistochemistry.

Results: TF and EphA2 co-localized constitutively in MDA-MB-231 cells, and addition of FVIla resulted in cleavage of EphA2 by a PAR2-independent mechanism. Overexpression of TF in U251 glioblastoma cells lead to co-localization with EphA2 at the leading edge and FVIla-dependent cleavage of EphA2. FVIla potentiated ephrin-A1-induced cell rounding and retraction fiber formation in MDA-MB-231 cells through a RhoA/ROCK-dependent pathway that did not require PAR2-activation. TF and EphA2 were expressed in colorectal cancer specimens, and were significantly correlated.
\end{abstract}

Conclusions: These results suggest that TF/FVIla-EphA2 cross-talk might potentiate ligand-dependent EphA2 signaling in human cancers, and provide initial evidence that it is possible for this interaction to occur in vivo.

Keywords: Tissue Factor, Coagulation factor, EphA2, Colorectal cancer, Cell signaling

\section{Background}

The Eph receptors are the largest family of receptor tyrosine kinases (RTKs) in humans with 14 members. Eph receptors are activated by cell-bound ephrin ligands, and the Eph-ephrin system governs contact-dependent intercellular communication controlling a wide array of biological processes such as development, tissue organization and cell migration $[1,2]$. EphA2 of the A type Eph subclass is expressed at low levels in differentiated tissues but expression frequently increases in advanced cancers, implicating EphA2 in tumor progression [3]. The

\footnotetext{
* Correspondence: oskar.eriksson@medsci.uu.se; agneta.siegbahn@medsci.uu.se ${ }^{1}$ Department of Medical Sciences, Clinical Chemistry \& Science for Life Laboratory, Uppsala University, Uppsala, Sweden
}

Full list of author information is available at the end of the article preferred ligand for EphA2 is ephrin-A1 [4], and ligation of EphA2 by ephrin-A1 leads to the formation of multimeric receptor-ligand clusters that activate a signaling response that controls cytoskeletal dynamics and cell morphology. While ligand-dependent EphA2-activation has been considered tumor suppressive, recent reports have highlighted a role for EphA2-ephrin-A1 signaling in tumor cell plasticity and a shift from mesenchymal to amoeboid morphology $[5,6]$ and increased single cell invasion [7]. In addition, oncogenic EphA2 signaling has been proposed to be ligand-independent, drawing from the observations of decreased expression of the ephrinA1 ligand paralleling increased EphA2 expression in human cancers [8]. Miao et al. showed that EphA2 is a substrate and effector of PI3 kinase/Akt signaling through 
phosphorylation of serine 897 in the EphA2 cytoplasmic domain, a pathway by which EphA2 controls cancer cell motility and invasion independently of ephrin-A1 $[9,10]$.

Tissue Factor (TF) is the receptor and co-factor for coagulation factor VII/VIIa (FVII/FVIIa), a circulating serine protease. The proteolytic TF/FVIIa complex functions as the physiological trigger of blood coagulation and in addition activates cell signaling through mechanisms dependent or independent of protease-activated receptors (PARs) and the TF cytoplasmic domain [11]. TF expression is found in tumor cells [12], and in preclinical models, TF/FVIIa signaling has been implicated in tumor progression through effects on processes such as cell migration and angiogenesis [13, 14]. Furthermore, a clinically relevant role of the coagulation system in malignancies is evidenced by the increased risk of thrombosis in cancer patients. In contrast, anticoagulant treatment only modestly influences cancer incidence and survival in humans, and the effect seem to differ between cancer types [15].

We previously reported on a direct cleavage by TF/FVIIa in the ligand binding domains (LBD) of the Eph receptors EphB2 and EphA2. We also identified a conserved disulfide bond that kept the N-terminal fragment tethered to the receptors after cleavage [16]. In this study we set out to further explore how TF/FVIIa influences EphA2 signaling and activity. We report herein that TF and EphA2 co-localizes in MDA-MB-231 breast cancer cells with constitutive high TF expression and in TF transfected U251 glioblastoma cells, and that FVIIa sensitizes MDA-MB-231 cells to ephrin-A1-mediated cytoskeletal reorganization and cell rounding independently of PAR2-activation through a RhoA/ROCK pathway. EphA2 and TF were co-expressed in a cohort of human colorectal cancer specimens, providing evidence that the prerequisites for TF-EphA2 crosstalk in vivo are present.

\section{Methods \\ Reagents}

Antibodies towards EphA2 (6997), pS897-EphA2 (6347), pY588-EphA2 (12677) and GAPDH (2118) were from Cell Signaling Technology. The RhoA antibody (ARH04) was from Cytoskeleton. The TF antibody (clone 10H10) was a kind gift from Professor J Morrissey (University of Illinois) and the PAR2 blocking antibody was a kind gift from Professor W Ruf (Scripps Institute). PI3 kinase inhibitor LY294002 was from Calbiochem and ROCK inhibitor Y-27632 from Sigma.

\section{Cell culture}

MDA-MB-231 cells were obtained from the American Type Culture Collection and cultured in complete RPMI 1640 medium. For experiments, cells were seeded in individual wells and left to attach over night. Cells were then switched to medium containing $0.1 \%$ FBS, for the
FVIIa groups supplemented with $10 \mathrm{nM}$ FVIIa for $1 \mathrm{~h}$ and then stimulated with ephrin-A1 or Fc control as indicated in the figure legends. Prior to experiments, ephrin-A1 was preclustered for $1 \mathrm{~h}$ at room temperature with anti-human Fc goat IgG (Jackson ImmunoResearch) at 1:10 concentration. Preclustered Fc fragments (Jackson Immunoresearch) were used as controls. In some cases, cells were pretreated for $30 \mathrm{~min}$ with inhibitors prior to stimulations.

U251 cells were from Cell Line Services and were cultured in complete DMEM medium. Experiments were performed in DMEM with $0.1 \%$ FBS.

\section{SDS-PAGE and Western blot}

SDS-PAGE and Western blot was performed using the Novex Bis-Tris gel system (Life Technologies) as previously described [14].

\section{mRNA analyses}

Total RNA was extracted from cells by Trizol $^{\circ}$ (Life Technologies) using standard protocols, and converted to cDNA using oligoDT primers. Quantitative real-time PCR (qPCR) was performed using Assays on demand (Applied Biosystems) for IL8 with $\beta 2$-microglobulin as housekeeping gene on an ABI prism 7500 system. Results were calculated using the comparative CT method for separate tubes.

\section{siRNA knock-down of RhoA}

MDA-MB-231 cells were transfected with $10 \mathrm{nM}$ RhoA siRNA (Silencer select, Ambion) using Lipofectamine RNAiMAX (Life Technologies) according to instructions from the manufacturer. Cells were assayed $48 \mathrm{~h}$ after transfection. Efficiency of protein knock-down was analyzed by Western blot.

\section{In situ proximity ligation assay}

The assay was performed with reagents supplied by the manufacturer (Olink Bioscience) and according to instructions supplied with the kit. In brief, MDA-MB-231 cells were grown on chamber slides (Lab Tek), fixed in $4 \%$ PFA/PBS, blocked and incubated with antibodies towards TF and EphA2, which were bound by secondary antibodies connected to specific oligonucelotides that ligate when they are in close proximity. Ligated oligonucleotides then serve as template for a rolling-circle amplification and the amplification products were visualized by fluorescently labeled probes. Cell nuclei were stained with DAPI and images captured with a 40x objective using a Zeiss Axioimager fluorescence microscope.

\section{Confocal microscopy}

For microscopy experiments, cells were grown on 8-well chamber slides (Lab Tek), and then washed with PBS and fixed in $4 \%$ PFA. Cells were permeabilized with $0.2 \%$ 
Triton X-100 and subsequently blocked in $2 \%$ BSA for $30 \mathrm{~min}$. Antibody incubations were performed for $1 \mathrm{~h}$ at room temperature for primary antibodies (EphA2 1:200, TF 1:500) and $30 \mathrm{~min}$ in the dark at room temperature for secondary antibodies (1:1000) (Molecular Probes). Staining of the actin cytoskeleton with phalloidin-FITC (Sigma) diluted 1:500 was performed together with the secondary antibodies. Slides were washed with PBS between all steps, and mounted in Vectashield mounting medium with DAPI and sealed with nail varnish. Confocal images were captured with a Zeiss LSM710 confocal microscope using the 40x or 63x objectives.

\section{Assay for cell rounding and retraction fiber formation} MDA-MB-231 cells were seeded on 8-well chamber slides (Lab-Tek) coated with $10 \mu \mathrm{g} / \mathrm{ml}$ collagen IV (Sigma) and left to attach over night. After treatments, cells were washed with PBS and fixed in $4 \%$ PFA/PBS. The cytoskeleton was stained by FITC-conjugated phalloidin (Sigma) for $30 \mathrm{~min}$ at room temperature protected from light. Slides were then washed, mounted in mounting media with DAPI and sealed with nail varnish. Images were captured using an Axiovert $40 \mathrm{CFL}$ inverted epifluorescence microscope (Zeiss) and the 40x objective. 3-4 images per well were taken at random locations and the percentage of cells with rounded morphology and retraction fibers was quantified according to Taddei et al. [17].

\section{TF overexpression}

U251 cells were transfected to transiently overexpress TF by using Lipofectamine 3000 (Life Technologies) and a plasmid encoding untagged human TF (Origene). Briefly, cells were seeded in 24-well plates, left to attach over night and transfected with $400 \mathrm{ng}$ DNA. Lipofectamine without DNA was used as control, and stimulations were performed $24 \mathrm{~h}$ post transfection in low serum DMEM.

\section{Immunohistochemistry (IHC) of colorectal cancer specimens}

The patient cohort used in the study contained nonconsecutive cases diagnosed with colorectal cancer between 1990 and 2003 in the Uppsala region in Sweden, collected with the purpose to screen for protein expression differences between disease stages and between normal colorectal tissue, cancer and metastases. The cohort included 60 patients, with 20 (33\%) patients each in stages I, II and III. 41 (68 \%) cases were colon cancers and $19(32 \%)$ cases were rectal cancers. 10 cases each of colorectal normal tissues and adenomas as well as 20 cases of lymph node or distant metastases were also included. Tumor and patient characteristics were based on the original histopathology reports and the patients' clinical records.
All tumor material was present as formalin-fixed paraffin-embedded tissue in duplicate cores on tissue microarrays (TMAs), constructed at the SciLife Laboratory Tissue Profiling Facility at Uppsala University as described previously [18]. Expression of TF and EphA2 was detected by IHC using a rabbit polyclonal TF antibody developed by the Human Protein Atlas project [19] and a rabbit monoclonal EphA2 antibody (6997, Cell Signaling Technology). Automated IHC staining were performed as previously described [20], using a LabVision Autostainer 480S (ThermoFisher Scientific). Microarray sections were baked over night, deparaffinized, hydrated in graded alcohols and blocked for endogenous peroxidase using $0.3 \%$ hydrogen peroxide. Following antigen retrieval, sections were stained with primary antibody (30 min) and secondary dextran polymer visualization system (30 $\mathrm{min})$, followed by the addition of diaminobenzidine as chromogen. All solutions except primary antibodies were obtained from Laboratory Vision (Laboratory Vision). Sections were counterstained in Mayer's hematoxylin (Histolab), before dehydration and mounting of coverslip. Stained slides were digitalized by scanning, using an Aperio ScanScope XT Slide Scanner (Aperio Technologies). Tumor cell staining was annotated semi-quantitatively with respect to staining intensity and fraction of positive cells. Intensity was graded as negative, weak, moderate or strong, and graded in six fractions $(0-1 \% ; 2-10 \% ; 11-25 \% ; 26-$ $50 \%, 51-75 \%$; $>75 \%$ ) and specimens with moderate or strong staining in more than $2 \%$ of tumor cells were considered positive.

During TMA sectioning 6 primary cancer cases and 3 metastases were lost or compromised, resulting in TMA cores with no representative tumor tissue present. These cases were not annotated and excluded from all statistical analyses.

\section{Statistics}

Statistics were performed using the GraphPad Prism (GraphPad Software) and Statistica (Statsoft Scandinavia) softwares. Unpaired two-tailed t-test was used to compare experimental groups. For comparison of TF and EphA2 expression in colorectal cancer nonparametric correlation was calculated according to Spearman, and Chi-squared tests were used to compare groups defined by TF and/or EphA2. P-values equal to or below 0.05 were considered statistically significant.

\section{Results}

\section{Subcellular localization of TF and EphA2}

We recently identified EphB2 and EphA2 as novel proteolytical substrates of TF/FVIIa, and located the cleavage site to a conserved arginine residue in the ligand-binding domain [16]. Here we set out to further analyze the EphA2 cleavage mechanism. As seen 
in Fig. 1, EphA2 is cleaved upon stimulation of MDA-MB-231 breast cancer cells with FVIIa, with the truncated EphA2 isoform appearing as band migrating around $95 \mathrm{kDa}$ on SDS-PAGE. In line with a direct cleavage mechanism, we previously showed that EphB2 was cleaved independently of proteolytic activation of the prototypic TF/FVIIa signaling receptor PAR2. Here we confirmed the PAR2-independence for EphA2 cleavage, as formation of the truncated EphA2 species by TF/FVIIa was not prevented by a PAR2-blocking antibody or the $10 \mathrm{H} 10$ anti-TF antibody specifically preventing PAR2-activation [21] (Fig. 1a), demonstrating a similar mechanism as for EphB2. The PAR2-blocking antibody was verified in our lab previously [22] and we also found that the $10 \mathrm{H} 10$ antibody prevented TF/FVIIa-PAR2 induced IL8 mRNA transcription as has been reported by others [21] (Fig. 1a).

These results supported a direct cleavage mechanism, which would require a co-localization between the protease and the substrate. Using the in situ proximity ligation method [23] to detect protein interactions we found that TF and EphA2 constitutively co-localized in MDA-MB-231 cells as measured by an abundance of signals corresponding to TF and

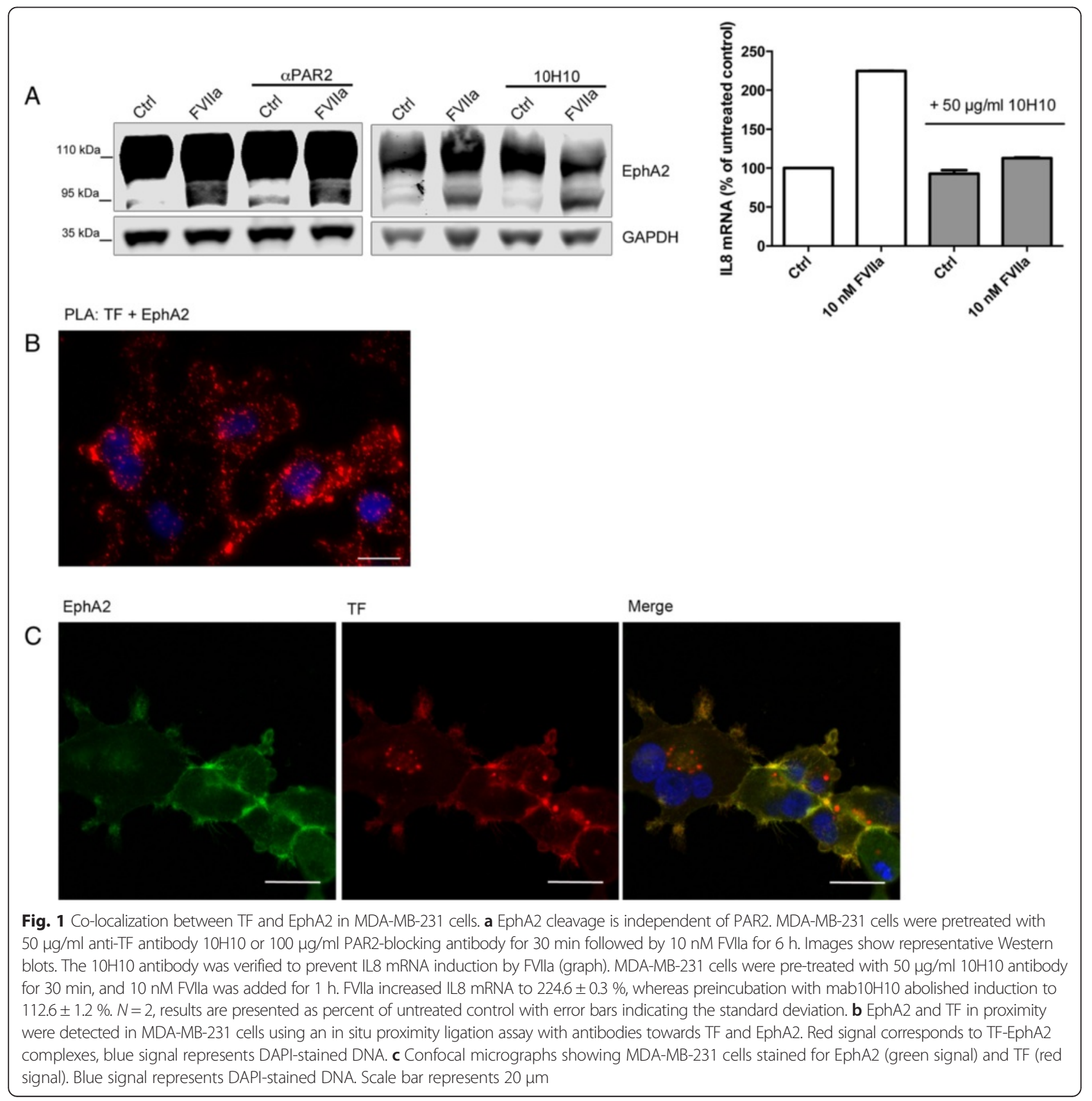


EphA2 in close proximity (Fig. 1b). We also immunostained MDA-MB-231 cells for TF and EphA2 and generated micrographs by confocal microscopy. TF and EphA2 both localized to cell membranes and colocalization was especially evident at cell-cell contacts (Fig. 1c), supporting an association between TF/FVIIa and EphA2. Secondary antibody controls showed no evidence for unspecific staining (Additional file 1). We compared these results to the U251 glioblastoma cell line, which expresses high levels of EphA2 but low amounts of TF, and confocal microscopy analysis showed a strong membranous EphA2 staining but a weak TF signal (Fig. 2a). Furthermore, EphA2 cleavage by FVIIa was not detected in these cells even after prolonged stimulations (Fig. 2c). We reasoned that a higher expression of TF than what was present in

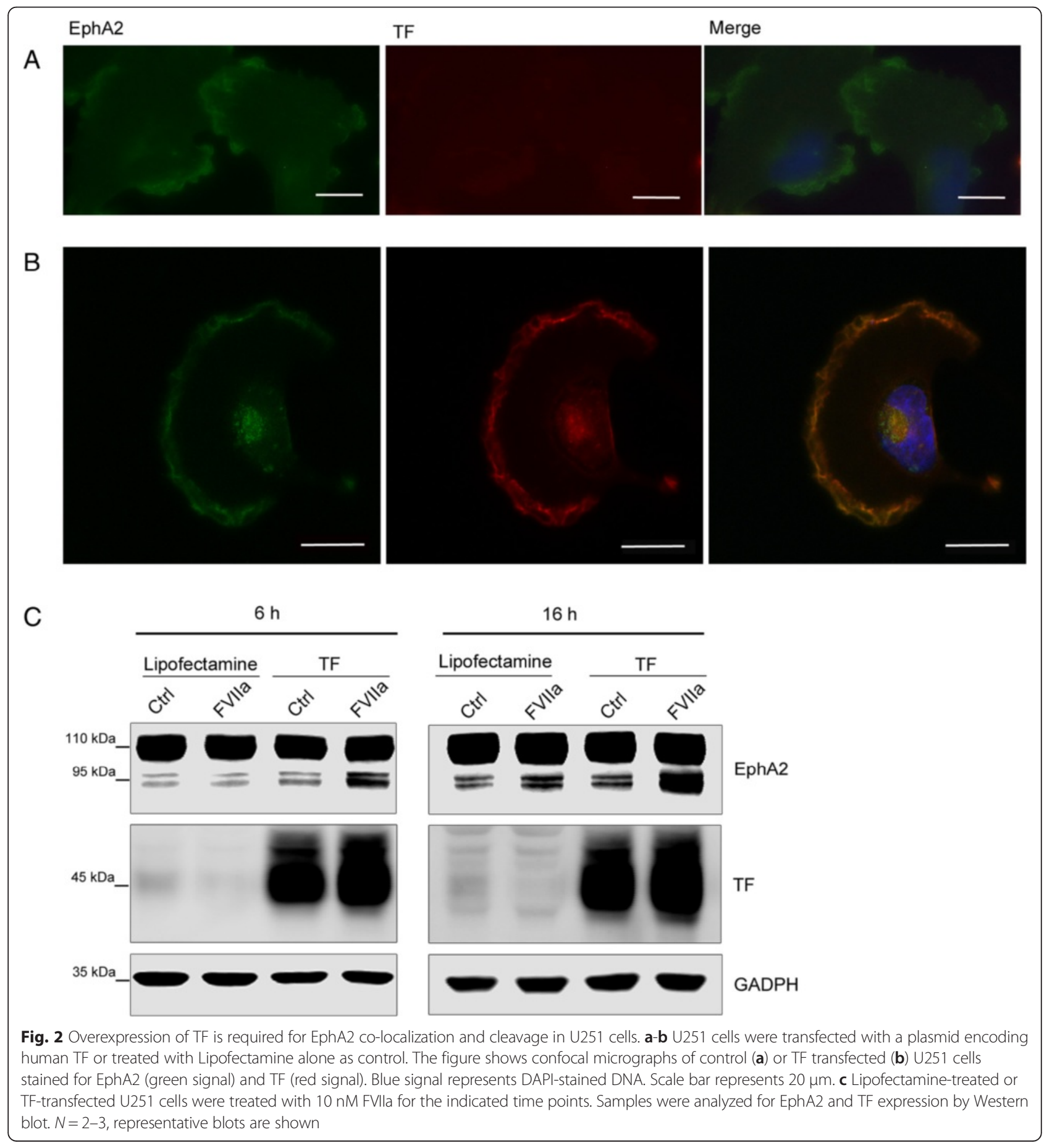


wild-type cells was necessary to allow sufficient complex formation with EphA2 at the cell surface, and in order to test this hypothesis we increased TF expression in these cells by transient overexpression. In contrast to wild type cells, TF appeared in transfected cells as an intense membranous staining with strong clustering at the leading edge and evident colocalization with EphA2 (Fig. 2b). In TF-transfected, but not wild-type cells, stimulation with $10 \mathrm{nM}$ FVIIa resulted in robust EphA2 cleavage indicating that high levels of TF expression resulting in co-localization with EphA2 is necessary for FVIIa to be able to cleave EphA2 (Fig. 2c).
FVIla potentiates ephrin-A1 induced cell rounding independently of PAR2-cleavage

Given the interaction between TF and EphA2 we next set out to investigate how formation of the TF/FVIIa complex would affect EphA2 signaling and its activation by the ligand ephrin-A1. Ligand-dependent forward signaling by EphA2 frequently targets the cytoskeleton, with EphA2 activation by ephrin-A1 leading to cytoskeletal rearrangements and cell rounding [17]. We stained MDA-MB-231 cells with phalloidin to visualize the actin cytoskeleton and found that EphA2 was enriched at clusters of dynamic actin fibers and at cell-cell contacts (Fig. 3a).

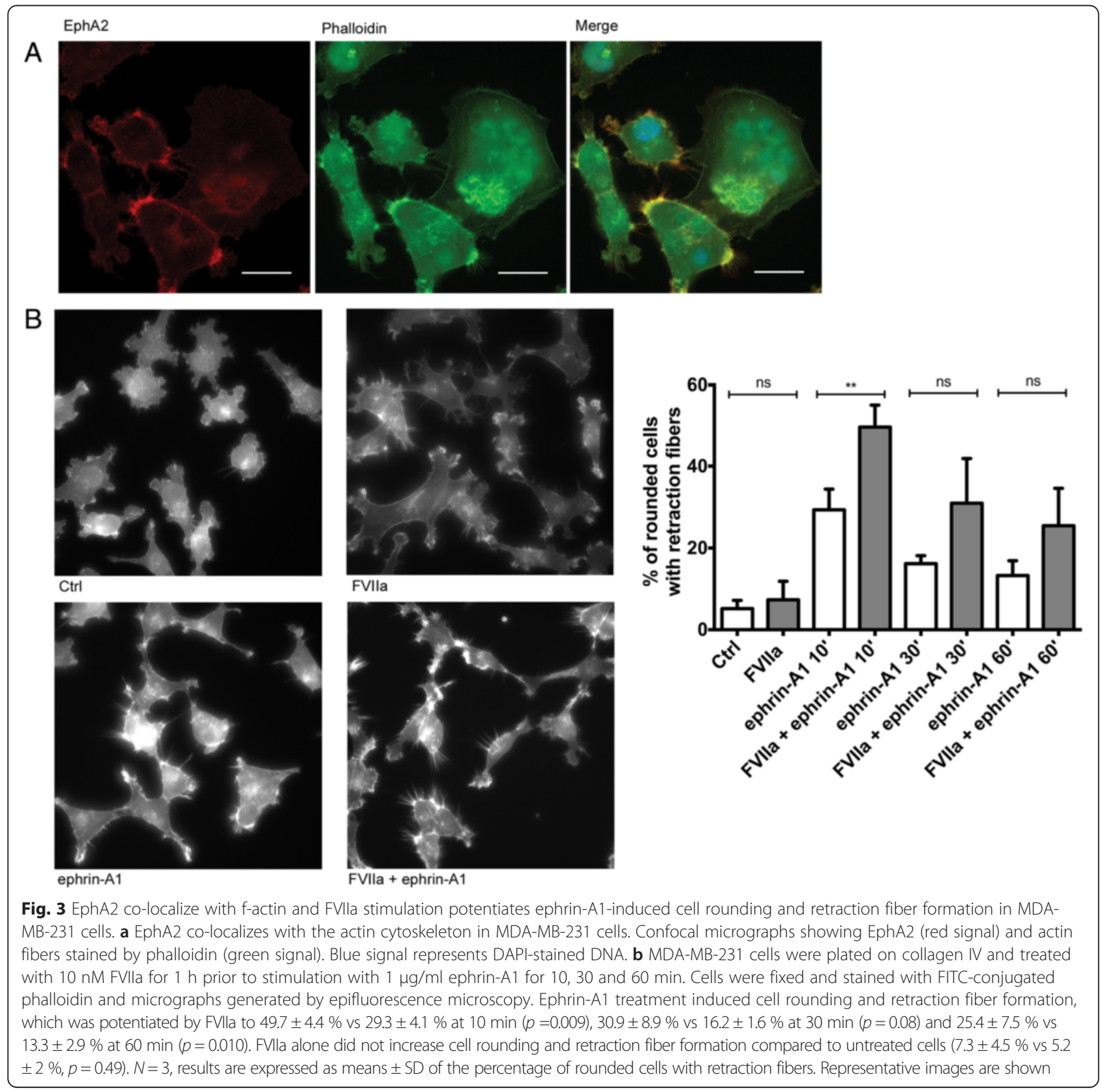


As demonstrated by others [17, 24], stimulation with ephrin-A1 caused a transient increase in cell rounding which peaked at $10 \mathrm{~min}$. Phalloidin staining revealed an accumulation of actin fibers at cell borders and an increase in retraction fibers, which were formed as cells rounded up and retracted their protrusions [25]. To investigate a role for TF/FVIIa in this process cells were pre-incubated with $10 \mathrm{nM}$ FVIIa, and then simulated with ephrin-A1 followed by phalloidin staining. In this context FVIIa alone caused no detectable changes in cell morphology. However, upon FVIIa pretreatment the cellular response to ephrin-A1 was greatly enhanced. The fraction of rounded cells with retraction fibers upon ephrin-A1 stimulation was increased by FVIIa preincubation at all time points, demonstrating a potentiation of ligand-dependent EphA2 activation (Fig. 3b).

As FVIIa cleaved EphA2 independently of PAR2 we tested the requirement of PAR2 in this context. Blocking experiments with an anti-PAR2 antibody and the anti-TF $10 \mathrm{H} 10$ antibody which selectively prevents PAR2 activation did not interfere with the synergistic effects of FVIIa and ephrin-A1 on cell rounding, demonstrating that this occurs independently of PAR2 (Fig. 4). Experiments with active site-inhibited FVII

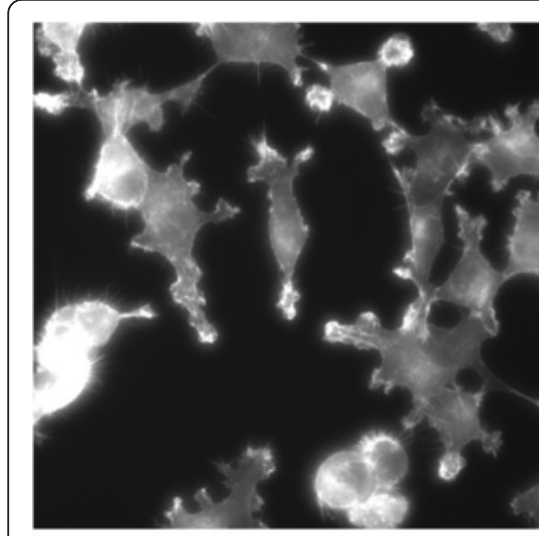

FFR-FVII + ephrin-A1

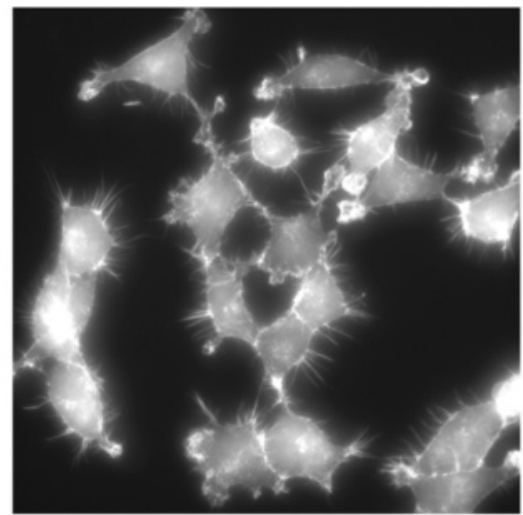

FVIla + ephrin-A1 + $\alpha$ PAR2

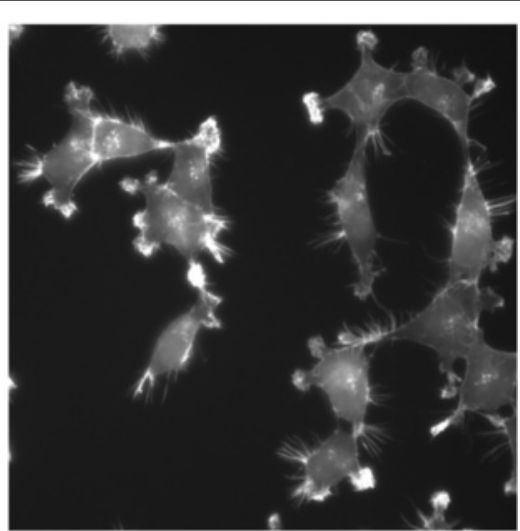

$\mathrm{FVIla}+$ ephrin-A1 + $10 \mathrm{H} 10$

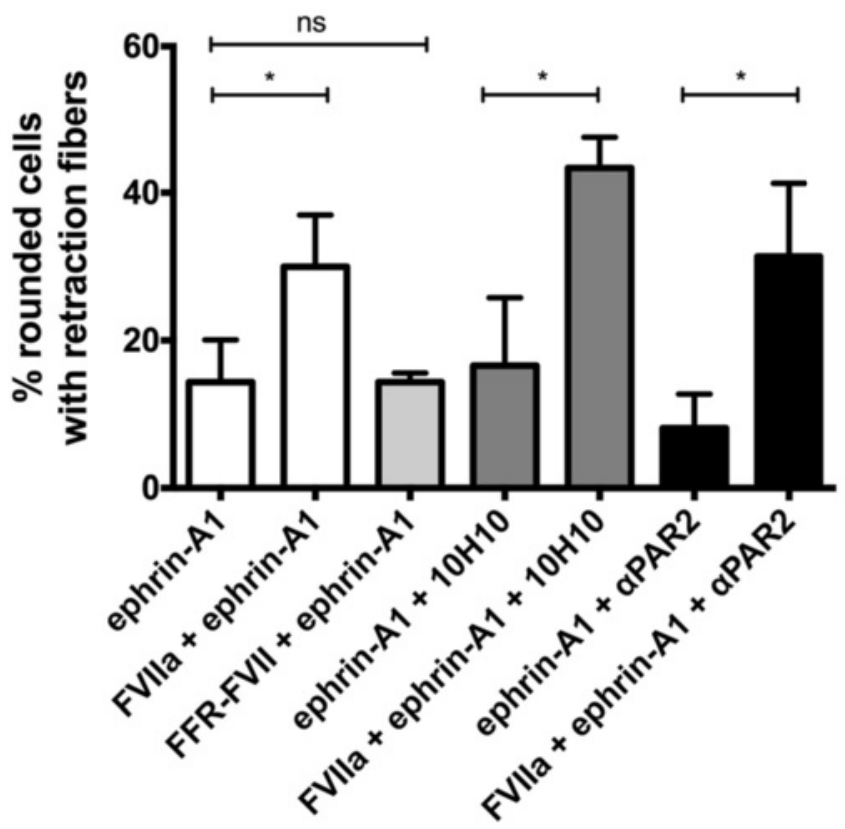

Fig. 4 Potentiation of ephrin-A1-induced cell rounding and retraction fiber formation by FVIla is independent of PAR2. MDA-MB-231 cells were pretreated with $50 \mu \mathrm{g} / \mathrm{ml}$ anti-TF antibody $10 \mathrm{H} 10$ or $100 \mu \mathrm{g} / \mathrm{ml}$ PAR2-blocking antibody for $30 \mathrm{~min}$, stimulated with $10 \mathrm{nM}$ FVlla for $1 \mathrm{~h}$ and then $1 \mu \mathrm{g} / \mathrm{ml}$ ephrin-A1 for $10 \mathrm{~min}$. Alternatively, $10 \mathrm{nM}$ active-site inhibited FVII (FFR-FVII) was added instead of FVIlla. Potentiation of cell rounding and retraction fiber formation was not prevented by the anti TF $10 \mathrm{H} 10$ antibody $(43.4 \pm 4.2 \%$ vs $16.6 \pm 9.2 \%, p=0.01)$ or a PAR2-blocking antibody $(31.4 \pm 9.9 \%$ vs $8.1 \pm 4.6 \%, p=0.02)$, FFR-FVII did not increase cell rounding and retraction fiber formation together with ephrin-A1 (14.3 $\pm 5.7 \%$ vs $14.4 \pm 1.2 \%, p=0.99)$. $N=3$, results are expressed as means \pm SD of the percentage of rounded cells with retraction fibers. Representative images are shown 
(FFR-FVII) confirmed the requirement for the proteolytical activity of FVIIa to synergistically enhance the ephrin-A1 response (Fig. 4).

\section{Cell rounding induced by FVIla and ephrin-A1 is dependent on a RhoA/ROCK pathway}

We next sought to gain insight into the downstream signaling mechanisms. A serine residue in the cytoplasmic domain of EphA2, serine 897 (S897), was recently discovered as an important phosphorylation site mediating cell motility downstream of PI3K/Akt signaling [9]. Western blots of FVIIa-treated MDA-MB-231 cells revealed a strong increase in $\mathrm{S} 897$ phosphorylation by $10 \mathrm{nM}$ FVIIa, which was completely abolished by the PI3 kinase inhibitor LY294002 (Fig. 5a). In contrast, EphA2 cleavage was not affected by PI3 kinase inhibition (Fig. 5a), in agreement with a direct cleavage by FVIIa and demonstrating that TF/FVIIa targets EphA2 by two independent mechanisms. We tested the PI3Kdependence in the cell rounding assay, but the PI3K inhibitor LY294002 did not affect the synergistic effect of FVIIa and ephrin-A1, ruling out a mechanism dependent on this pathway (Fig. 5b).

Instead, ligand-dependent EphA2 activity targeting the cytoskeleton has been reported to be dependent on RhoA signaling [26]. Preincubation of cells with $10 \mu \mathrm{M}$ Y-27632, an inhibitor of the RhoA signaling effector ROCK, abolished cell rounding by ephrin-A1 and FVIIa (Fig. 5b). We confirmed this result by knocking down RhoA with siRNA. RhoA-depleted cells were almost completely unresponsive to ephrin-A1 with regards to cytoskeletal rearrangements and maintained a spread morphology both when treated with ephrin-A1 alone or in combination with FVIIa, showing a mechanism dependent on a RhoA/ROCK pathway downstream of EphA2 (Fig. 5c).

These results demonstrated a synergistic effect of ephrin-A1 and FVIIa in EphA2 activation independent of PAR2-signaling and PI3K-dependent serine phosphorylation of EphA2, and EphA2 was cleaved by TF/FVIIa in a PAR2- and PI3K-independent manner. Yet, the cleavage by TF/FVIIa occurs in the EphA2 LBD. However, the Nterminal fragment remains attached to the truncated EphA2 species by a disulfide bond [16], raising the possibility that it might still be responsive to ephrin-A1. Being an RTK, EphA2 has intrinsic tyrosine kinase activity that is activated by ligand-binding and we examined EphA2 activation by FVIIa and ephrin-A1 by using an antibody towards phosphorylated tyrosine 588 (Y588) in the EphA2 cytoplasmic domain. Western blots showed low tyrosine phosphorylation in the basal state, which was slightly but consistently increased by FVIIa as seen on high-exposure Western blots (Fig. 6a). Ephrin-A1 treatment resulted in a rapid and strong tyrosine phosphorylation of full-length
EphA2 that, however, was not further increased by FVIIa pretreatment. The cleaved EphA2 species was also rapidly tyrosine phosphorylated by ephrin-A1, which was detected after $1 \mathrm{~h}$ or $6 \mathrm{~h}$ pre-treatment with FVIIa (Fig. 6b-c). Cleaved EphA2 also appeared to undergo rapid ligand-induced downregulation, as we consistently found a time-dependent reduction of the band corresponding to cleaved EphA2 after ephrin-A1 stimulation, as seen on the $10 \mathrm{~min}$ ephrin-A1 time point in Fig. 6b. Taken together, these results indicate that cleaved EphA2 is activated in response to stimulation with ephrin-A1.

\section{TF and EphA2 are co-expressed in advanced stage colorectal cancers and appear close to necrotic and invasive areas}

TF expression has previously been detected in many solid tumors, including colorectal cancers [27], and has been linked to tumor progression on an experimental level using animal models and in vitro cell culture systems [13]. To explore if a role for TF-EphA2 cross-talk in this context is plausible we stained a cohort of colorectal cancer specimens for TF and EphA2 by IHC and scored their expression levels in tumor cells. IHC stainings on normal colorectal mucosa showed that epithelial cells in the large intestine were mostly negative for TF, while strong staining was seen in the epithelial lining. EphA2 expression was present in the most apical parts of the colorectal epithelium while basal portions of the glands were negative, in agreement with previous observations [28] and demonstrating antibody specificity (Additional file 1). EphA2 expression then reappeared in cancer specimens, along with increased positivity for TF. TF expression was detected in $28 \%$ of primary cancers and $29 \%$ of lymph gland or distant metastases, and EphA2 in $59 \%$ of cases in both groups (Table 1). Interestingly, annotation scores for TF and EphA2 expression correlated (Spearman Rho 0.48, $p<0.001$ ), with $87 \%$ of TF positive primary tumors and $100 \%$ of TF positive metastases also being positive for EphA2, demonstrating that TF and EphA2 are co-expressed in colorectal carcinomas. We also investigated if combined expression of TF and EphA2 was related to tumor characteristics in primary tumors. Co-expression of TF and EphA2, compared to negativity for either of the two proteins, was significantly associated with poorly differentiated histology (high grade tumors), as six out of 13 (46\%) cases in this group were double positive compared to only seven out of 39 (18 \%) cases with intermediate/high differentiation (low to intermediate grade) $(p=0.042)$ (Table 2). Notably, staining of serial sections revealed that TF and EphA2 positivity appeared to be concentrated to clusters of tumor cells close to necrotic areas or small clusters of budding tumor cells invading through the stroma (Fig. 7a-b). 
A

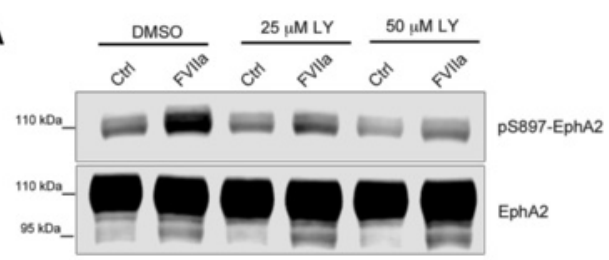

B
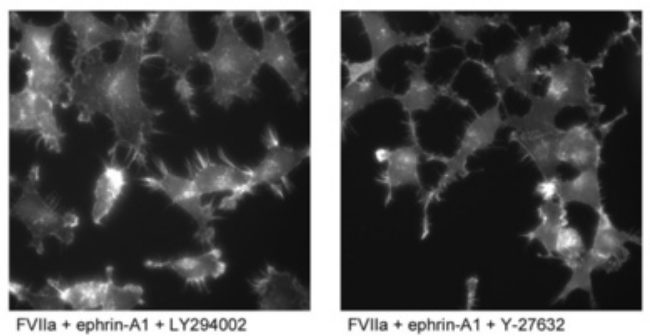

FVlla + ephrin-A1 + Y-27632
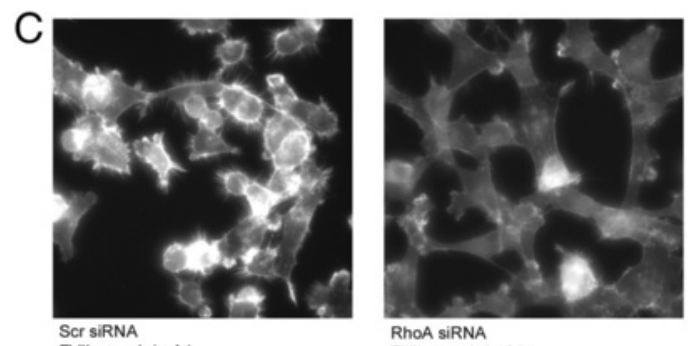

RhOA siRNA

FVIla + ephrin-A1
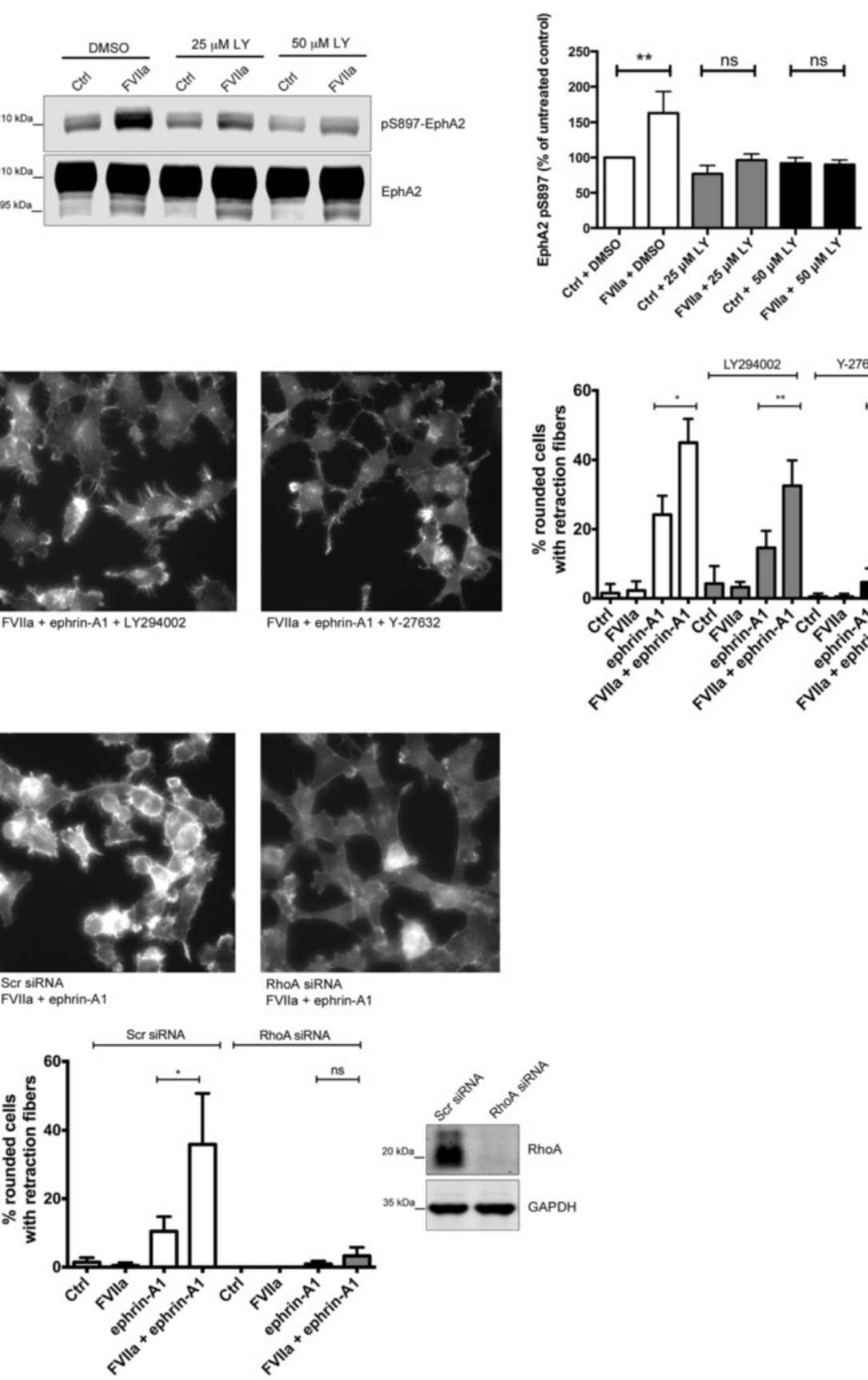

Fig. 5 Cell rounding and retraction fiber formation in response to FVlla and ephrin-A1 is dependent on a RhoA/ROCK pathway. a MDA-MB-231 cells were pre-incubated with either DMSO or 25 or 50 MM PI3K inhibitor LY294002 before $10 \mathrm{nM}$ FVlla was added for $1 \mathrm{~h}$. Samples were analyzed by Western blot. S897-phosphorylation was increased to $163.1 \pm 30.2 \%$ of control in DMSO-treated cells $(p=0.006)$, whereas $25 \mu \mathrm{M}$ or $50 \mu \mathrm{M}$ LY294002 abolished induction by FVIla to $96.4 \pm 8.6 \%$ vs $77.1 \pm 11.7 \%(p=0.08)$ or $89.9 \pm 6.7 \%$ vs $91.7 \pm 8.1 \%(p=0.78)$, respectively. Values are expressed as \% of control. $N=3-4$, results are presented as means \pm SD. $\mathbf{b}$ MDA-MB-231 cells were pretreated with $10 \mu \mathrm{M}$ ROCK-inhibitor Y-27632 or $25 \mu \mathrm{M}$ PI3K inhibitor LY294002 for $30 \mathrm{~min}$ and then stimulated as in Fig. 4. Y-27632 pre-treatment abolished the effects of ephrin-A1 as well as the potentiation by FVIla ( $4.8 \pm 1.3 \%$ vs $4.6 \pm 4.1 \%, p=0.93$ ), while LY294002 had no effect ( $32.5 \pm 7.3 \%$ vs $14.6 \pm 4.9 \%, p=0.007)$. $N=3-4$, results are expressed as means \pm SD of the percentage of rounded cells with retraction fibers. $\mathbf{c}$ RhoA expression was silenced by siRNA in MDA-MB-231 cells, and knock-down was verified by Western blot. In Scr-transfected cells FVlla potentiated ephrin-A1 induced cell rounding (35.87 \pm 14.80 vs $10.49 \pm 4.29 \%$, $p=0.046)$, whereas RhoA knock-down cells were unresponsive to ephrin-A1 and FVlla $(3.30 \pm 2.50 \%$ vs $0.92 \pm 0.88 \%, p=0.19)$. $N=3$, results are expressed as means \pm SD of the percentage of rounded cells with retraction fibers 
A
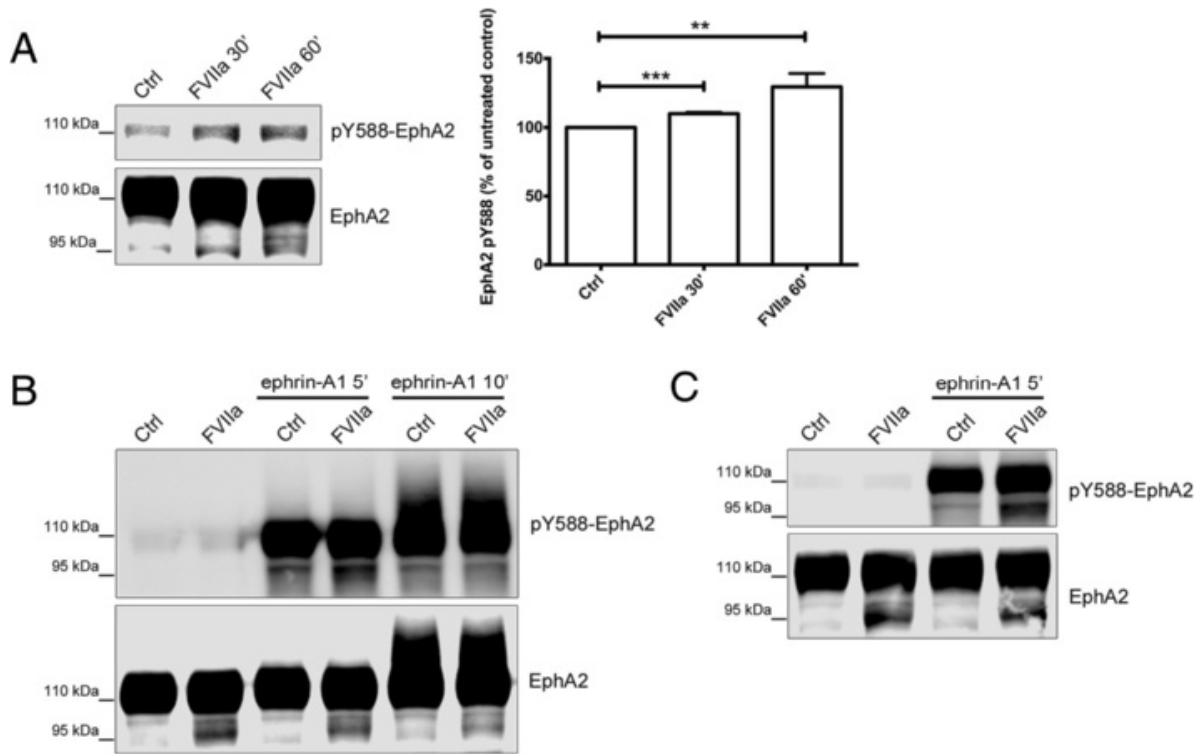

$95 \mathrm{kDa}$

Fig. 6 EphA2 is tyrosine phosphorylated by FVlla and ephrin-A1. a MDA-MB-231 cells were treated with $10 \mathrm{nM}$ FVlla and samples were analyzed by Western blot for EphA2 phosphorylation on tyrosine 588 (Y588) and total EphA2 protein. FVlla increased the phosphotyrosine signal to $110.0 \pm 1.02 \%$ $(p<0.001)$ after $30 \mathrm{~min}$ and $129.2 \pm 9.82 \%(p=0.0067)$ after $60 \mathrm{~min} . N=3$, results are presented as means \pm SD. b MDA-MB-231 cells were pretreated with $10 \mathrm{nM} \mathrm{FVlla}$ for $1 \mathrm{~h}$ and then stimulated with $1 \mathrm{\mu g} / \mathrm{ml}$ ephrin-A1-Fc for 5 or $10 \mathrm{~min}$. c MDA-MB-231 cells were pretreated with $10 \mathrm{nM} \mathrm{FVIla} \mathrm{for} 6 \mathrm{~h}$ and then stimulated with $1 \mu \mathrm{g} / \mathrm{ml}$ ephrin-A1-Fc for $5 \mathrm{~min}$. Samples were analyzed by Western blot as in (a). $N=2-3$, representative gels are shown

\section{Discussion}

We report herein on a close cross-talk between TF and the tyrosine kinase receptor EphA2 and present evidence of a role for the TF/FVIIa complex as a co-receptor and signaling partner of EphA2 with possible implications in human cancer. We observed that TF and EphA2 colocalized in MDA-MB-231 breast cancer cells with high endogenous TF expression, and in U251 glioblastoma cells with forced overexpression of TF. EphA2 and TF appeared to cluster at cell-cell contacts and subcellular compartments with an accumulation of dynamic actin cytoskeleton, in agreement with literature documenting

Table 1 Association between TF and EPHA2 expression in colorectal cancer

\begin{tabular}{lllll}
\hline & $\begin{array}{l}\text { Total } \\
N(\%)\end{array}$ & $\begin{array}{l}\text { TF positive } \\
N(\%)\end{array}$ & $\begin{array}{l}\text { TF negative } \\
\text { N (\%) }\end{array}$ & $P$ value \\
\hline $\begin{array}{l}\text { Primary cancers } \\
\text { All cases }\end{array}$ & 54 & 15 & 39 & $\mathrm{n} / \mathrm{a}$ \\
$\begin{array}{l}\text { EphA2 } \\
\text { positive }\end{array}$ & $32(59)$ & $13(87)$ & $19(49)$ & $\mathbf{0 . 0 1 1}$ \\
$\quad$ negative & $22(41)$ & $2(13)$ & $20(51)$ & \\
$\begin{array}{l}\text { Metastases } \\
\text { All cases }\end{array}$ & 17 & 5 & 12 & $\mathrm{n} / \mathrm{a}$ \\
$\begin{array}{l}\text { EphA2 } \\
\text { positive }\end{array}$ & $10(59)$ & $5(100)$ & $5(42)$ & $\mathbf{0 . 0 2 6}$ \\
negative & $7(41)$ & $0(0)$ & $7(58)$ & \\
\hline
\end{tabular}

$P$-values in bold indicate statistically significant results
Table 2 Associations between TF and EPHA2 positive colorectal cancers and patient and tumor characteristics

\begin{tabular}{|c|c|c|c|c|}
\hline Characteristic & $\begin{array}{l}\text { Total } \\
\text { N (\%) }\end{array}$ & $\begin{array}{l}\text { TF \& } \\
\text { EphA2 pos } \\
\text { N (\%) }\end{array}$ & $\begin{array}{l}\text { TF or } \\
\text { EphA2 neg } \\
\text { N (\%) }\end{array}$ & $P$ value \\
\hline All cases & 54 & 13 & 41 & $\mathrm{n} / \mathrm{a}$ \\
\hline \multicolumn{5}{|l|}{ Stage } \\
\hline $\begin{array}{l}\text { Stage I } \\
\text { Stage II } \\
\text { Stage III }\end{array}$ & $\begin{array}{l}20(37) \\
19(35) \\
15(28)\end{array}$ & $\begin{array}{l}5(38.5) \\
3(23) \\
5(38.5)\end{array}$ & $\begin{array}{l}15(37) \\
16(39) \\
10(24)\end{array}$ & 0.49 \\
\hline \multicolumn{5}{|l|}{ Grade } \\
\hline $\begin{array}{l}\text { Low/Intermediate } \\
\text { High (Low diff) } \\
\text { Missing }\end{array}$ & $\begin{array}{l}39(75) \\
13(25) \\
2\end{array}$ & $\begin{array}{l}7(54) \\
6(46)\end{array}$ & $\begin{array}{l}32(82) \\
7(18)\end{array}$ & 0.042 \\
\hline \multicolumn{5}{|l|}{ Location } \\
\hline $\begin{array}{l}\text { Colon } \\
\text { Rectum }\end{array}$ & $\begin{array}{l}37(69) \\
17(31)\end{array}$ & $\begin{array}{l}10(77) \\
3(23)\end{array}$ & $\begin{array}{l}27(66) \\
14(34)\end{array}$ & 0.45 \\
\hline \multicolumn{5}{|l|}{ Sex } \\
\hline $\begin{array}{l}\text { Male } \\
\text { Female }\end{array}$ & $\begin{array}{l}23(43) \\
31(57)\end{array}$ & $\begin{array}{l}7(54) \\
6(46)\end{array}$ & $\begin{array}{l}16(39) \\
25(61)\end{array}$ & 0.35 \\
\hline \multicolumn{5}{|l|}{ Ki67 } \\
\hline $\begin{array}{l}>25 \% \\
<25 \%\end{array}$ & $\begin{array}{l}43(80) \\
11(20)\end{array}$ & $\begin{array}{l}11(85) \\
2(15)\end{array}$ & $\begin{array}{l}32(78) \\
9(22)\end{array}$ & 0.61 \\
\hline \multicolumn{5}{|l|}{ CK20 } \\
\hline $\begin{array}{l}\text { Positive } \\
\text { Negative }\end{array}$ & $\begin{array}{l}49(91) \\
5(9)\end{array}$ & $\begin{array}{l}12(92) \\
1(8)\end{array}$ & $\begin{array}{l}37(90) \\
4(10)\end{array}$ & 0.82 \\
\hline
\end{tabular}

$P$-values in bold indicate statistically significant results 


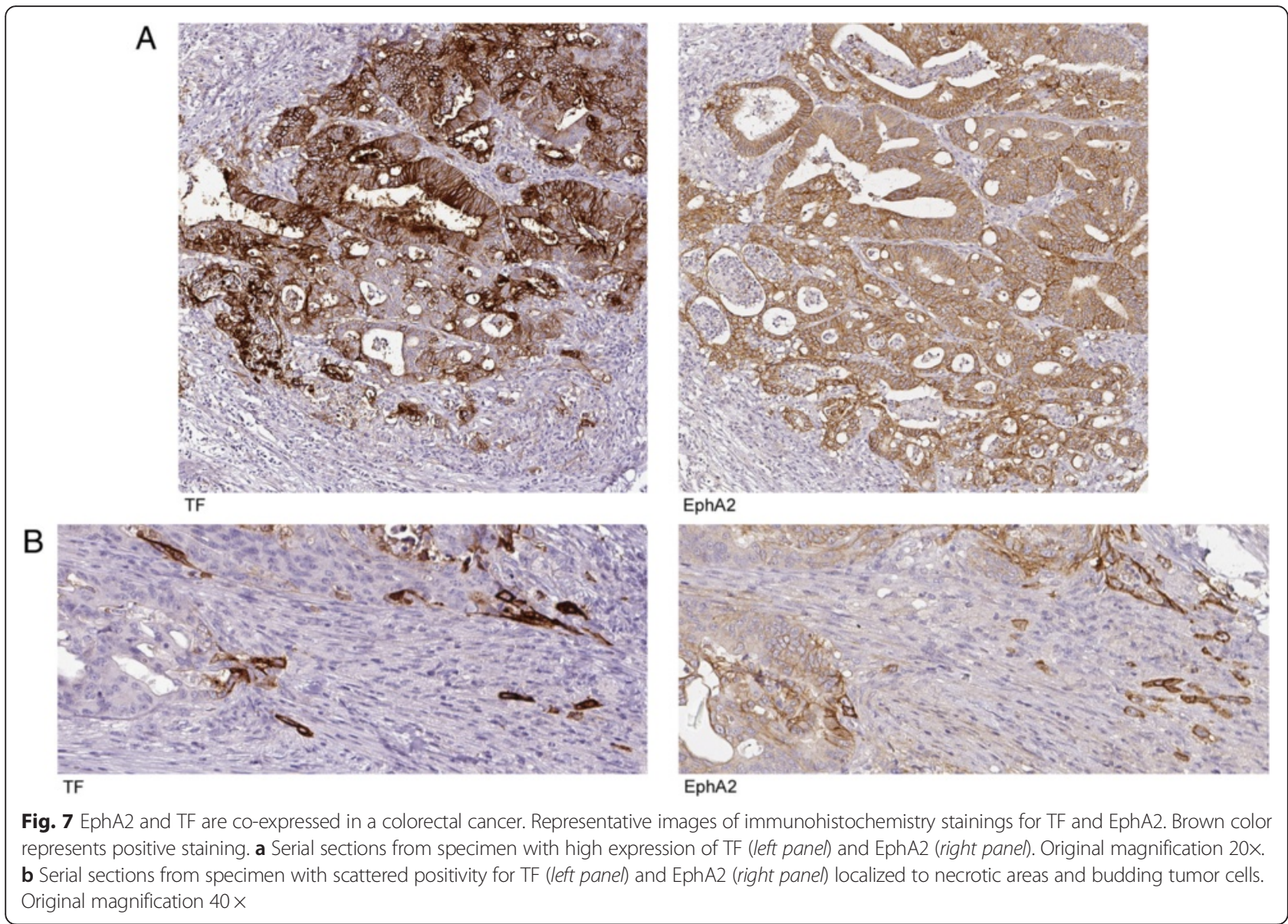

an important role for EphA2 in regulating cytoskeletal dynamics $[29,30]$. Importantly, we found that FVIIa potentiated the cellular response to ephrin-A1 as measured by increased cell rounding and retraction fiber formation upon stimulation, demonstrating that FVIIa and ephrinA1 act synergistically to enhance ligand-dependent EphA2 signaling. By antibody blocking experiments, we show that this is an event uncoupled from PAR2activation, in line with biochemical data demonstrating direct cleavage of EphA2 by TF/FVIIa, and supporting a role of the TF/FVIIa complex acting as a co-receptor in EphA2 signaling.

EphA2 is cleaved by FVIIa after a conserved arginine residue in the J-K loop of the LBD, and we previously showed that the cleaved fragment remains associated to the truncated EphA2 by a conserved disulfide bond (Cys70-Cys188), and the LBD is also stabilized by an additional disulfide (Cys105-Cys115). Since the Cys70Cys188 disulfide will prevent dissociation of the $\mathrm{N}$ terminal fragment we predict that the structure of the EphA2 LBD is largely retained after cleavage, with the cleavage leading to a local conformational change in the J-K loop. We hypothesize that cleavage by TF/FVIIa might, by a yet unidentified exact mechanism, enhance
EphA2 activation by its ligand. As it was tyrosine phosphorylated and rapidly underwent ligand-induced degradation, our data indicate that the cleaved fragment indeed contributes to ephrin-A1-dependent signaling and that the cleavage does not results in a ligand-unresponsive form of EphA2. Of note, as the synergism between FVIIa and ephrin-A1 was PAR2-independent in line with the cleavage mechanism, it appears not to be an unrelated event resulting from PAR2 activation by TF/FVIIa.

EphA2 tyrosine phosphorylation was very low in unstimulated cells, which was expected since MDA-MB231 cells are reported to express very low amounts of the ephrin-A1 ligand [8]. We observed a slight increase of phosphorylation at the Y588 site by FVIIa, but since this effect was negligible compared to the response induced by ephrin-A1 the relevance of this observation with regards to synergism between FVIIa and ephrin-A1 is not clear at the moment. Of note, we previously analyzed this cell line using antibody arrays [16], where FVIIa decreased the phosphotyrosine signal for EphA2 and as we noted, since those experiments were run with native samples a decrease in signal can equally well correspond to masking of the phosphotyrosine epitope by proteins recruited to the activated receptor [31]. 
Even though a large number of studies have confirmed an important role of EphA2 in human cancers, there are controversies regarding the contributions of ligand dependent and ligand independent signaling. Ephrin-A1 ligation of EphA2 and subsequent receptor activation has been proposed to be tumor suppressive, although other studies point to an important role for kinase dependent EphA2 activity in cancer development. Cell rounding and retraction is a recognized event in Ephephrin signaling, and requires RhoA activation [6, 7], in accordance with our results. Interestingly, recent work suggest that EphA2-ephrin-A1 signaling may support cell migration and invasion in prostate cancer [5] and melanoma cells [6] in this manner. Here, RhoAmediated mesenchymal-to-amoeboid transition has been implicated, indicating a qualitative shift in cell migration characterized by cell rounding, single cell invasion and a squeezing movement style, leading to tissue invasion and tumor dissemination [32, 33]. Also, other studies demonstrated that repulsive EphA2-RhoA signaling among cancer cells may serve to allow tumor cells to disperse from the main tumor mass [26]. Importantly, contact inhibition of locomotion which may occur as a consequence of repulsive interactions between Eph and ephrin expressing cells does not need to lead to a complete inhibition of motility but rather a change in direction, in certain contexts contributing to a shift from collective to single cell cancer invasion [34]. In this context, our results demonstrating a synergism of FVIIa and ephrin-A1 in EphA2 activation lead us to hypothesize that TF/FVIIa may serve to increase EphA2-mediated cell dispersion upon contact with ephrin-A1 expressing cells, and that FVIIa may facilitate ephrin-A1 induced mesenchymal-to-amoeboid transition in this context.

EphA2 signaling is characterized by a high level of complexity and several seemingly independent activation mechanisms, as demonstrated by the present study where FVIIa caused both a direct cleavage and S897 phosphorylation of EphA2. While cleavage was insensitive to PI3 kinase inhibition, S897 phosphorylation was completely abolished in agreement with the notion that this is a common event downstream of activation of PI3 kinase. Cell rounding and retraction fiber formation was not affected by PI3K inhibition, showing a dissociation between EphA2-pS897 signaling and ligand-dependent EphA2 activation as has been proposed elsewhere [9]. The role and function of FVIIa-induced EphA2 S897phosphorylation was not elucidated in this study, and its role as an effector downstream of FVIIa-induced PI3K activation will be an important issue for further studies.

In support of the relevance of TF/FVIIa-EphA2 crosstalk we present descriptive data that TF and EphA2 were co-expressed to a high extent in a human cancer material, and TF positivity was with a few exceptions only found in EphA2 expressing tumors. TF and EphA2 have separately been reported to be expressed in various cancers, but our study is the first to demonstrate coexpression in the same tumor specimens. In contrast to our experimental work that was performed in breast cancer and glioblastoma cell lines, we used another cancer type, colorectal cancer, to demonstrate the association between TF and EphA2 in human tumor tissue. Although these are distinct cancer types, both TF and EphA2 expression appears to foremost be a feature of advanced cancers, and TF expression is regulated by common oncogenic mutations [35]. Indeed, EphA2 has been linked to colorectal cancer development as targeted EphA2 gene disruption was found to reduce intestinal tumorigenesis in the APC/Min + mouse model [36]. We found that co-expressing tumors were enriched among high-grade cases, supporting the view that these results may be a feature of poorly differentiated human cancers rather than a tissue specific event in colorectal neoplasms. TF expression was, for both primary cancers and metastases, found in a minority of cases, and our results indicate that TF and EphA2 co-expression is an event that occurs in a subset of colorectal cancers that are characterized by low differentiation. As a large number of cases were TF negative, this might be a mechanism that contributes to tumorigenesis in a subset of tumors, whereas other oncogenic pathways drive more differentiated cancers. Here, future studies on larger clinical materials will have to provide answers on the possible impact on patient survival and outcome.

We previously noted that higher concentrations of FVIIa were needed for cleavage of EphA2 compared to cleavage of another Eph receptor, EphB2. In the present study, overexpression of TF was required to achieve EphA2 cleavage by FVIIa in U251 cells and it thus appears that very high levels of TF, such as may be found in transformed cells are necessary for this to occur. However, high levels of both TF and EphA2 are recognized events in malignant cells, and we used a colorectal cancer material to show that co-expression of TF and EphA2 indeed occurs in vivo. In addition, cleavage of cellular subpopulations with EphA2 co-localizing with TF may also play important biological roles even though these are events that are below the detection limit of Western blot assays.

\section{Conclusion}

In summary, we show with a proximity ligation assay and immunofluorescence that TF and EphA2 co-localize in cancer cell lines and that TF/FVIIa cleaves EphA2 in cells with high TF expression in a PAR2-independent manner. FVIIa stimulation increased ephrinA1-induced cell rounding mediated by a RhoA/ROCK pathway and thus potentiated ephrin-A1-EphA2 cytoskeletal rearrangements, 
with a potential role in mesenchymal-to-amoeboid transition mediated by the EphA2-ephrin-A1 axis. We also present initial evidence that EphA2 and TF are co-expressed in vivo in poorly differentiated colorectal tumors, thus warranting further studies on their cooperative role in human cancers.

\section{Additional file}

Additional file 1: Supplemental Figures. (PDF 2.19 MB)

\section{Abbreviations}

FFR-FVII, active site-inhibited FVII; FVII/FVIla, coagulation factor VII/VIla; IHC, immunohistochemistry; LBD, ligand-binding domain; PAR2, proteaseactivated receptor 2; RTK, receptor tyrosine kinase; TF, Tissue Factor; TMA, tissue microarray.

\section{Acknowledgements}

The authors would like to acknowledge researchers in the Human Protein Atlas Project, Uppsala University, for skillful technical assistance.

\section{Funding}

The study was supported by grants from the Swedish Research Council, the Selanders Foundation and the Swedish Science for Life Laboratory.

\section{Availability of data and materials}

Data and materials are available from the corresponding authors upon request.

\section{Authors' contributions}

OE: designed research, performed research, analyzed data and wrote the paper, ÅT: performed research, analyzed data AA: organized the immunohistochemistry work, GH and SN: annotated immunohistochemistry stainings, AS: designed research, analyzed data and wrote the paper. All authors reviewed and approved the final version of the paper.

\section{Competing interests}

The authors declare that they have no competing interests.

\section{Consent for publication}

Human tissue samples used for protein expression analyses were collected and handled in accordance with Swedish laws and regulation and obtained from the Department of Pathology, Uppsala University Hospital, Uppsala, Sweden as part of the sample collection governed by the Uppsala Biobank (http://www.uppsalabiobank.uu.se/en/) All human tissue samples used in the present study were anonymized in accordance with approval and advisory report from the Uppsala Ethical Review Board (Reference \# 2002-577, 2005-338 and 2007-159), and consequently the need for informed consent was waived by the ethics committee.

\section{Ethics approval}

Ethical permission of the collection of tumor material for TMAs and analyses of protein expression was obtained from the local ethics review boards in Uppsala (References \# 2007-159, 2011-473) and Lund (Reference \# 2007-445).

\section{Author details}

'Department of Medical Sciences, Clinical Chemistry \& Science for Life Laboratory, Uppsala University, Uppsala, Sweden. ²Department of Immunology, Genetics \& Pathology \& Science for Life Laboratory, Uppsala University, Uppsala, Sweden. ${ }^{3}$ Lab Surgpath, The Human Protein Atlas Project, Mumbai Site, Mumbai, India.

Received: 19 July 2015 Accepted: 20 May 2016

Published online: 31 May 2016

\section{References}

1. Janes PW, Nievergall E, Lackmann M. Concepts and consequences of Eph receptor clustering. Semin Cell Dev Biol. 2012;23:43-50.
2. Lisabeth EM, Falivelli G, Pasquale EB. Eph receptor signaling and ephrins. Cold Spring Harb Perspect Biol. 2013;5:a009159.

3. Brantley-Sieders DM. Clinical relevance of Ephs and ephrins in cancer: Lessons from breast, colorectal, and lung cancer profiling. Semin Cell Dev Biol. 2012;23:102-8 [Signalling via Eph Receptors and Ephrins].

4. Beauchamp A, Debinski W. Ephs and ephrins in cancer: Ephrin-A1 signalling. Semin Cell Dev Biol. 2012;23:109-15.

5. Taddei ML, Parri M, Angelucci A, Bianchini F, Marconi C, Giannoni E, Raugei G, Bologna M, Calorini L, Chiarugi P. EphA2 induces metastatic growth regulating amoeboid motility and clonogenic potential in prostate carcinoma cells. Mol Cancer Res. 2011;9:149-60.

6. Parri M, Taddei ML, Bianchini F, Calorini L, Chiarugi P. EphA2 reexpression prompts invasion of melanoma cells shifting from mesenchymal to amoeboid-like motility style. Cancer Res. 2009;69:2072-81.

7. Sugiyama N, Gucciardo E, Tatti O, Varjosalo M, Hyytiäinen M, Gstaiger M, Lehti K. EphA2 cleavage by MT1-MMP triggers single cancer cell invasion via homotypic cell repulsion. J Cell Biol. 2013;201:467-84.

8. Macrae M, Neve RM, Rodriguez-Viciana P, Haqq C, Yeh J, Chen C, Gray JW, McCormick F. A conditional feedback loop regulates Ras activity through EphA2. Cancer Cell. 2005;8:111-8.

9. Miao H, Li D-Q, Mukherjee A, Guo H, Petty A, Cutter J, Basilion JP, Sedor J, Wu J, Danielpour D, Sloan AE, Cohen ML, Wang B. EphA2 mediates ligand-dependent inhibition and ligand-independent promotion of cell migration and invasion via a reciprocal regulatory loop with Akt. Cancer Cell. 2009;16:9-20.

10. Miao H, Gale NW, Guo H, Qian J, Petty A, Kaspar J, Murphy AJ, Valenzuela DM, Yancopoulos G, Hambardzumyan D, Lathia JD, Rich JN, Lee J, Wang B. EphA2 promotes infiltrative invasion of glioma stem cells in vivo through cross-talk with Akt and regulates stem cell properties. Oncogene. 2015;34: 558-67.

11. Åberg M, Eriksson O, Siegbahn A. Tissue factor noncoagulant signaling: mechanisms and implications for cell migration and apoptosis. Semin Thromb Hemost. 2015;41:691-9.

12. Callander NS, Varki N, Rao LV. Immunohistochemical identification of tissue factor in solid tumors. Cancer. 1992;70:1194-201.

13. Ruf W, Disse J, Carneiro-Lobo TC, Yokota N, Schaffner F. Tissue factor and cell signalling in cancer progression and thrombosis. J Thromb Haemost. 2011;9 Suppl 1:306-15.

14. van den Berg WY, Osanto S, Reitsma PH, Versteeg HH. The relationship between tissue factor and cancer progression: insights from bench and bedside. Blood. 2012;119:924-32.

15. Cunningham MS, Preston RJS, O'Donnell JS. Does antithrombotic therapy improve survival in cancer patients? Blood Rev. 2009;23:129-35.

16. Eriksson O, Ramström M, Hörnaeus K, Bergquist J, Mokhtari D, Siegbahn A. The Eph tyrosine kinase receptors EphB2 and EphA2 are novel proteolytic substrates of tissue factor/coagulation factor Vlla. J Biol Chem. 2014;289:32379-91.

17. Taddei ML, Parri M, Angelucci A, Onnis B, Bianchini F, Giannoni E, Raugei G, Calorini L, Rucci N, Teti A, Bologna M, Chiarugi P. Kinase-dependent and -independent roles of EphA2 in the regulation of prostate cancer invasion and metastasis. Am J Pathol. 2009;174:1492-503.

18. Kampf C, Olsson I, Ryberg U, Sjöstedt E, Pontén F. Production of tissue microarrays, immunohistochemistry staining and digitalization within the human protein atlas. J Vis Exp. 2012;63:3620.

19. Uhlén M, Björling E, Agaton C, Szigyarto CA-K, Amini B, Andersen E, Andersson A-C, Angelidou P, Asplund A, Asplund C, Berglund L, Bergström K, Brumer H, Cerjan D, Ekström M, Elobeid A, Eriksson C, Fagerberg L, Falk R, Fall J, Forsberg M, Björklund MG, Gumbel K, Halimi A, Hallin I, Hamsten C, Hansson M, Hedhammar M, Hercules G, Kampf C, et al. A human protein atlas for normal and cancer tissues based on antibody proteomics. Mol Cell Proteomics. 2005;4:1920-32.

20. Segersten MU, Edlund EK, Micke P, De La Torre M, Hamberg H, Edvinsson ÅEL, Andersson SEC, Malmström P-U, Wester HK. A novel strategy based on histological protein profiling in-silico for identifying potential biomarkers in urinary bladder cancer. BJU Int. 2009;104:1780-5.

21. Versteeg $H H$, Schaffner F, Kerver M, Petersen HH, Ahamed J, FeldingHabermann B, Takada Y, Mueller BM, Ruf W. Inhibition of tissue factor signaling suppresses tumor growth. Blood. 2008;111:190-9.

22. Åberg $M$, Johnell $M$, Wickström M, Siegbahn A. Tissue Factor/FVlla prevents the extrinsic pathway of apoptosis by regulation of the tumor suppressor Death-Associated Protein Kinase 1 (DAPK1). Thromb Res. 2011;127:141-8.

23. Söderberg O, Leuchowius K-J, Gullberg M, Jarvius M, Weibrecht I, Larsson L$\mathrm{G}$, Landegren $\mathrm{U}$. Characterizing proteins and their interactions in cells and 
tissues using the in situ proximity ligation assay. Methods. 2008;45:227-32 Visualization of Molecular Processes in Cells Using Fluorescence Imaging]

24. Miao H, Burnett E, Kinch M, Simon E, Wang B. Activation of EphA2 kinase suppresses integrin function and causes focal-adhesion-kinase dephosphorylation. Nat Cell Biol. 2000;2:62-9.

25. Cramer LP, Mitchison TJ. Investigation of the mechanism of retraction of the cell margin and rearward flow of nodules during mitotic cell rounding. Mol Biol Cell. 1997;8:109-19.

26. Batson J, Maccarthy-Morrogh L, Archer A, Tanton H, Nobes CD. EphA receptors regulate prostate cancer cell dissemination through Vav2-RhoA mediated cell-cell repulsion. Biol Open. 2014;3:453-62.

27. Rao B, Gao Y, Huang J, Gao X, Fu X, Huang M, Yao J, Wang J, Li W, Zhang J, Liu $H$, Wang L, Wang J. Mutations of p53 and K-ras correlate TF expression in human colorectal carcinomas: TF downregulation as a marker of poor prognosis. Int J Colorectal Dis. 2011;26:593-601.

28. Kosinski C, Li VSW, Chan ASY, Zhang J, Ho C, Tsui WY, Chan TL, Mifflin RC, Powell DW, Yuen ST, Leung SY, Chen X. Gene expression patterns of human colon tops and basal crypts and BMP antagonists as intestinal stem cell niche factors. Proc Natl Acad Sci. 2007;104:15418-23.

29. Salaita K, Nair PM, Petit RS, Neve RM, Das D, Gray JW, Groves JT. Restriction of receptor movement alters cellular response: physical force sensing by EphA2. Science. 2010;327:1380-5.

30. Fang WB, Ireton RC, Zhuang G, Takahashi T, Reynolds A, Chen J. Overexpression of EPHA2 receptor destabilizes adherens junctions via a RhoA-dependent mechanism. J Cell Sci. 2008;121:358-68.

31. MacBeath G. Protein microarrays and proteomics. Nat Genet. 2002;32:526-32.

32. Wolf K, Mazo I, Leung H, Engelke K, von Andrian UH, Deryugina El, Strongin AY, Bröcker E-B, Friedl P. Compensation mechanism in tumor cell migration mesenchymal-amoeboid transition after blocking of pericellular proteolysis. J Cell Biol. 2003;160:267-77.

33. Huang B, Lu M, Jolly MK, Tsarfaty I, Onuchic J, Ben-Jacob E. The three-way switch operation of Rac1/RhoA GTPase-based circuit controlling amoeboidhybrid-mesenchymal transition. Sci Rep. 2014;4:6449.

34. Friedl P, Alexander S. Cancer invasion and the microenvironment: plasticity and reciprocity. Cell. 2011;147:992-1009.

35. Yu JL, May L, Lhotak V, Shahrzad S, Shirasawa S, Weitz Jl, Coomber BL, Mackman N, Rak JW. Oncogenic events regulate tissue factor expression in colorectal cancer cells: implications for tumor progression and angiogenesis. Blood. 2005:105:1734-41.

36. Bogan C, Chen J, O'Sullivan MG, Cormier RT. Loss of EphA2 receptor tyrosine kinase reduces Apcmin/+ tumorigenesis. Int J Cancer. 2009;124: 1366-71.

\section{Submit your next manuscript to BioMed Central and we will help you at every step:}

- We accept pre-submission inquiries

- Our selector tool helps you to find the most relevant journal

- We provide round the clock customer support

- Convenient online submission

- Thorough peer review

- Inclusion in PubMed and all major indexing services

- Maximum visibility for your research

Submit your manuscript at www.biomedcentral.com/submit

C Biomed Central 